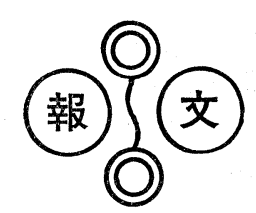

VIII族元素のアルミナ担持触媒上のメタノー

ルの分解およびスチームリフォーミング

-1979. 5. 28 受理一

岡山大学* 笠岡 成光, 白神隆

\section{1. 緒霅}

さきに石油代替資源・エネルギーの一つとしての天 然ガス利用の見直しとして, 著者らはメタン $\left(\mathrm{CH}_{4}\right)$ の水蒸気, 二酸化炭素, 酸素の各単独ガスおよびこれ らの混合ガスによる接触リフォーミングについて, 周 期律表 $\mathrm{VIII}$ 族金属の $\mathrm{Al}_{2} \mathrm{O}_{3}$ 担持触媒の調製法々併せて基 礎的な検討を行ない，適当な反応系ガス組成および温 度で, $\mathrm{CO}$ と $\mathrm{H}_{2}$ からなる合成ガスの得られること， また Ni や Ru 系の触媒がとくに有効であることなど の有意な結果・知見を報告した ${ }^{1)}$ 。しかし，液化天然が ス (主成分 $\left.\mathrm{CH}_{4}\right)$ は, メタノール $\left(\mathrm{CH}_{3} \mathrm{OH}\right)$ と比べる と, 安全運搬や備蓄に, かなりの設備と経費を必要と する。とくに将来の輸入天然ガスの生産地が遠隔地で あるような場合には，な打さら問題が生じてくる。そ こで生産地で, 天然ガスのリフォーミングによる合成 ガスから $\mathrm{CH}_{3} \mathrm{OH}$ 合成し (将来は, $\mathrm{CH}_{4}$ の直接酸化に よる合成が切望される), 消費地で, ふたたび $\mathrm{CH}_{3} \mathrm{OH}$ を合成ガスあるいは $\mathrm{H}_{2}$ 飞変換して用いることも起こ ってくるものと思われる。

$\mathrm{CH}_{3} \mathrm{OH}$ の分解については, Fort ら² $\mathrm{MgO}$ 上で 検討し, $\mathrm{CH}_{4}$ の副生等の生成ガス組成に関して報告し ている。また, $\mathrm{CH}_{3} \mathrm{OH}$ のスチームリフォーミングに ついては, Kobayashi ら゙は $\mathrm{Cu}$ を含む二成分系共沈 触媒で検討し, $\mathrm{Cu}-\mathrm{Al}_{2} \mathrm{O}_{3}$ 触媒が活性であること, ま た, この反応は $\mathrm{HCHO}, \mathrm{HCOOCH}_{3}$ 等を経て進行す ることなどを報告している。

著者らは， $\mathrm{CH}_{4}$ の各種ガス（上記）によるリフォー ミング1) 飞対して検討した汭族金属 (Ni, Co, Fe, Ru, $\mathrm{Rh}, \mathrm{Pt}, \mathrm{Pd})$ の $\mathrm{Al}_{2} \mathrm{O}_{3}$ 担持触媒を用いて, $\mathrm{CH}_{3} \mathrm{OH}$ の 接触分解 $\left(\mathrm{CH}_{3} \mathrm{OH} \rightarrow \mathrm{CO}+2 \mathrm{H}_{2}\right)$ 抢よびスチームリフ オーミング $\left(\mathrm{CH}_{3} \mathrm{OH}+\mathrm{H}_{2} \mathrm{O} \rightarrow \mathrm{CO}_{2}+3 \mathrm{H}_{2}\right)$ を試み, $\mathrm{CH}_{4}$ のリフォーミングに高い活性・選択性を示した $\mathrm{Ru}$ や $\mathrm{Ni}$ とは異なって, とくに $\mathrm{Pt} か ゙, \mathrm{CH}_{3} \mathrm{OH}$ の分解とス チームリフォーミングの両反応に対して, $\mathrm{CH}_{4}$ を副生

\footnotetext{
* 工学部合成化学教室 岡山市津島中3-1-1
}

せず，活性・選択性ともにきわめて高い触媒であるこ と, また $\mathrm{Co}$ は $\mathrm{CH}_{3} \mathrm{OH}$ の分解に対しては活性はそう 高くはないが，スチームリフォーミングでは， $\mathrm{H}_{2}$ 生成 量も多く, 有効な触媒であることなど有意な結果・知 見を得たので報告する。

\section{2. 反応の平衡論的考察}

$\mathrm{CH}_{3} \mathrm{OH}$ の分解抢よびスチームリフォーミング反応 ならびにこれらの反応関連して予測される副反応な ぞの主な見かけの反応式と，その反応熱㧍よび常圧平 衡定数を熱力学的数值 (各成分ガス等の標準生成熱, エントロピー抢よび定圧比熱の温度依存式）から敩密 に推算した值の一例をTable 1 亿総括して示した。す なわち, No. 1 とNo. 3 は目的とする反応であり，No.2 は $\mathrm{CO}$ の転化反応, No. 4 と No. 5 は $\mathrm{CH}_{3} \mathrm{OH}$ の分解(No. 1) が $\mathrm{HCHO}$ を経て進行すると仮想して，ちなみに示し たものであり， No.6〜No. 8 は $\mathrm{CO}$ と $\mathrm{CO}_{2}$ のメタネー ション反応， No. 9 と No.10は $\mathrm{CH}_{3} \mathrm{OH}$ の副反応，またNo. 11〜 N0.13は $\mathrm{CH}_{3} \mathrm{OH}$ および $\mathrm{CO}$ の分解による炭素析出 反応である。

つぎに, Fig. 1 にこれらの反応の常圧下の平衡変撸 率の一例 $\left(\mathrm{CH}_{3} \mathrm{OH}\right.$ 等の入口分压が0. 1atm の場合) 示した。Table 1の反応と併せて考察してみると, No. 3 の $\mathrm{CH}_{3} \mathrm{OH}$ のスチームリフォーミングは, Fig. 1 の 平衡変換率の数值からは, $100 \%$ 変換の可能性は考兄 られるが，この反応はN No.1の $\mathrm{CH}_{3} \mathrm{OH}$ の分解（吸熱反 応; 高温昰ど有利) と N 0.2 の CO の転化反応 (発熱反 応；低温注ど有利）の組合わ女（逐次区応）と考兄ら れるので, Fig. 2 飞CO の転化反応の平衡変換率の計 算值を示した。すなわち, 生成 $\mathrm{CO}$ を $100 \%$ 近く変換 させるためには，たと充ば $400^{\circ} \mathrm{C}$ 付近以上ではスチ一 厶モル比 $\left(\mathrm{H}_{2} \mathrm{O} / \mathrm{CO}\right.$ すなわち $\left.\mathrm{H}_{2} \mathrm{O} / \mathrm{CH}_{3} \mathrm{OH}\right)$ を4.0 付 近以上にしなければならないことが知られる。また， No. $6 \sim$ No. 8 のメタネーション反応の平衡値 (Fig. 1) からもわかるように, 触媒によっては, $\mathrm{CH}_{4}$ 生成の可 能性がある。な抢, 触媒劣化の要因の一つである炭素 
Table 1 Estimated values of heat of reaction, $\Delta \mathrm{H}$ and equilibrium constant, $K$ at cracking of methnol and reaction of methane with steam, etc.

\begin{tabular}{|c|c|c|c|c|c|c|c|}
\hline \multirow{2}{*}{ No. } & \multirow{2}{*}{ Apparent reaction equation } & \multicolumn{2}{|c|}{$\Delta \mathrm{H}(\mathrm{Kcal} / \mathrm{mol})$} & \multicolumn{4}{|c|}{$\mathrm{K}$} \\
\hline & & $25^{\circ} \mathrm{C}$ & $800^{\circ} \mathrm{C}$ & $25^{\circ} \mathrm{C}$ & $600^{\circ} \mathrm{C}$ & $800^{\circ} \mathrm{C}$ & $1,000^{\circ} \mathrm{C}$ \\
\hline 1 & $\mathrm{CH}_{3} \mathrm{OH} \longrightarrow \mathrm{CO}+2 \mathrm{H}_{2}$ & 21.7 & 24.0 & $4.85 \times 10^{-5}$ & $4.26 \times 10^{3}$ & $9.74 \times 10^{4}$ & $1.03 \times 10^{6}$ \\
\hline 2 & $\mathrm{CO}+\mathrm{H}_{2} \mathrm{O} \longrightarrow \mathrm{CO}_{2}+\mathrm{H}_{2}$ & -9.8 & -9.3 & $9.75 \times 10^{4}$ & $3.81 \times 10$ & $1.13 \times 10$ & 4.72 \\
\hline 3 & $\mathrm{CH}_{3} \mathrm{OH}+\mathrm{H}_{2} \mathrm{O} \longrightarrow \mathrm{CO}_{2}+3 \mathrm{H}_{2}$ & 11.8 & 14.7 & 4.75 & $1.63 \times 10^{5}$ & $1.11 \times 10^{6}$ & $4.90 \times 10^{6}$ \\
\hline 4 & $\mathrm{CH}_{3} \mathrm{OH} \longrightarrow \mathrm{HCHO}+\mathrm{H}_{2}$ & 20.4 & 21.4 & $7.78 \times 10^{-10}$ & $1.60 \times 10^{-2}$ & $2.62 \times 10^{-1}$ & 2.12 \\
\hline 5 & $\mathrm{HCHO} \longrightarrow \mathrm{CO}+\mathrm{H}_{2}$ & 1.3 & 2.6 & $6.25 \times 10^{4}$ & $2.66 \times 10^{5}$ & $3.72 \times 10^{5}$ & $4.87 \times 10^{5}$ \\
\hline 6 & $\mathrm{CO}+3 \mathrm{H}_{2} \longrightarrow \mathrm{CH}_{4}+\mathrm{H}_{2} \mathrm{O}$ & -49.3 & -52.2 & $7.90 \times 10^{24}$ & $1.56 \times 10^{7}$ & $1.73 \times 10^{4}$ & $1.06 \times 10^{2}$ \\
\hline 7 & $\mathrm{CO}_{2}+4 \mathrm{H}_{2} \longrightarrow \mathrm{CH}_{4}+2 \mathrm{H}_{2} \mathrm{O}$ & -39.4 & -42.9 & $8.10 \times 10^{19}$ & $4.08 \times 10^{5}$ & $1.53 \times 10^{3}$ & $2.23 \times 10$ \\
\hline 8 & $\mathrm{CO}+\mathrm{H}_{2} \longrightarrow \frac{1}{2} \mathrm{CH}_{4}+\frac{1}{2} \mathrm{CO}_{2}$ & -29.6 & -30.8 & $8.85 \times 10^{14}$ & $2.44 \times 10^{4}$ & $4.45 \times 10^{2}$ & $2.24 \times 10$ \\
\hline 9 & $\mathrm{CH}_{3} \mathrm{OH}+\mathrm{H}_{2} \longrightarrow \mathrm{CH}_{4}+\mathrm{H}_{2} \mathrm{O}$ & -27.6 & -28.2 & $3.86 \times 10^{20}$ & $6.66 \times 10^{10}$ & $1.69 \times 10^{9}$ & $1.09 \times 10^{8}$ \\
\hline 10 & $\mathrm{CH}_{3} \mathrm{OH}+\mathrm{CO} \longrightarrow \mathrm{CH}_{4}+\mathrm{CO}_{2}$ & -37.4 & -37.4 & $3.80 \times 10^{25}$ & $2.55 \times 10^{12}$ & $1.93 \times 10$ & 5. $18 \times 10^{8}$ \\
\hline 11 & $\mathrm{CH}_{3} \mathrm{OH} \longrightarrow \mathrm{C}+\mathrm{H}_{2}+\mathrm{H}_{2} \mathrm{O}$ & -9.7 & -8.2 & $4.88 \times 10^{11}$ & $3.01 \times 10^{8}$ & $1.03 \times 10^{8}$ & 4. $81 \times 10^{7}$ \\
\hline 12 & $\mathrm{CO} \longrightarrow \frac{1}{2} \mathrm{C}+\frac{1}{2} \mathrm{CO}_{2}$ & -20.6 & -20.7 & $3.15 \times 10^{10}$ & 1. $64 \times 10^{3}$ & 1. $10 \times 10^{2}$ & 1. $49 \times 10$ \\
\hline 13 & $\mathrm{CH}_{3} \mathrm{OH} \longrightarrow \frac{1}{2} \mathrm{C}+\frac{1}{2} \mathrm{CO}_{2}+2 \mathrm{H}_{2}$ & 1.1 & 3.3 & $1.53 \times 10^{6}$ & $7.01 \times 10^{6}$ & $1.07 \times 10^{7}$ & $1.54 \times 10^{7}$ \\
\hline
\end{tabular}

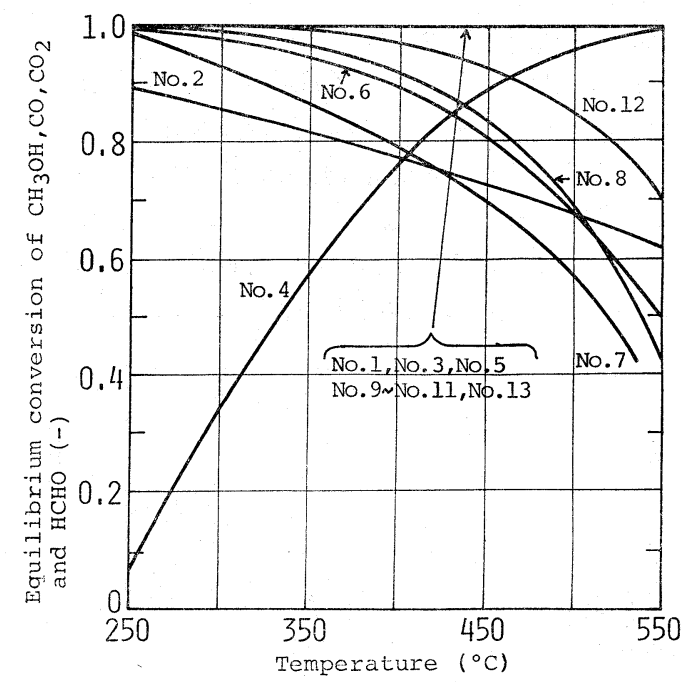

Estimation conditions :

Total pressure : latm, Partial pressure : $0.1 \mathrm{~atm}$ for $\mathrm{CH}_{3} \mathrm{OH}, \mathrm{CO}, \mathrm{CO}_{2}$ or $\mathrm{HCHO}$, and stoichiometric ratio for other reactions(Table 1 ); balanced with $\mathrm{N}_{2}$

Fig. 1 Estimated values of equilibrium conversion of verious reaction on reforming of $\mathrm{CH}_{3} \mathrm{OH}$ shown in Table 1

析出は, No.12の $\mathrm{CO}$ の分解 (発熱反応) および $\mathrm{CH}_{3} \mathrm{OH}$ の分解によるN No.11 (発熱反応) やNo.13 (吸熱反応) 的 平衡論的には大いに考えられるが, $\mathrm{CH}_{3} \mathrm{OH}$ の分解に よって生成した CO の分解が主であろうと考えられ

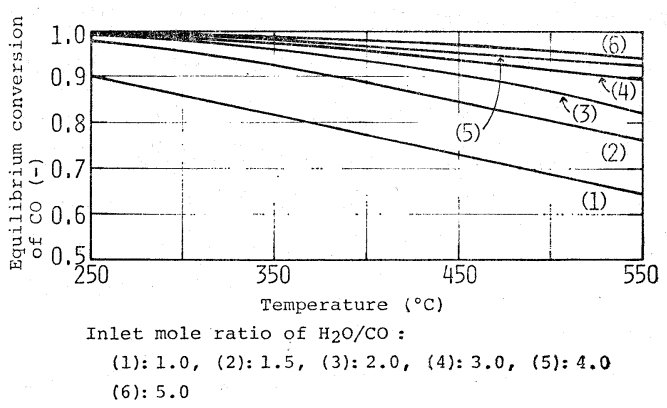

Fig. 2 Estimated values of equilibrium conversion of $\mathrm{CO}$ in reaction of $\mathrm{CO}+\mathrm{H}_{2} \mathrm{O}$ $\longrightarrow \mathrm{CO}_{2}+\mathrm{H}_{2}$

る。

\section{3. 触 姲}

用いた触媒は Table 2 に示したVII族元素 (Co, Ni， $\mathrm{Fe}, \mathrm{Pt}, \mathrm{Rh}, \mathrm{Ru}, \mathrm{Pd})$ の $\mathrm{Al}_{2} \mathrm{O}_{3}$ 担持物であり, 前報 ${ }^{1)}$ $\mathrm{CH}_{4}$ のリフォーミングで検討した至適な条件で調製し たものである。担体 $\mathrm{Al}_{2} \mathrm{O}_{3}$ は水沢化学工業侏)の $\mathrm{Neo}$ bead CB $5 \mathrm{~S}$ を破砕・ふるい別けし，-14/+28メッシ ュ (平均粒径 $0.9 \mathrm{~mm}$ ) のものを精製空気流中, $1,100^{\circ} \mathrm{C}$ で 3 時間, 前焼成した。この担体を所定量の触媒原料 塩溶液 (Table 2) 中に室温下, 25時間, 漫漬し, 蒸 発乾固後のものを実験にさきだち, $\mathrm{H}_{2}$ 流中, 室温から $550^{\circ} \mathrm{C}$ まで昇温 $\left(10^{\circ} \mathrm{C} / \mathrm{min}\right.$ ) し, $550^{\circ} \mathrm{C}$ で約 1 時間（昇 温開始からの時間を合わせて 2 時間), 還元した。 
Table 2 Raw material salts ofcatalysts employed

\begin{tabular}{|c|c|c|c|c|c|}
\hline \multirow{2}{*}{$\begin{array}{c}\text { Catalyst } \\
\text { (wt } \% \text { ) }\end{array}$} & \multirow[b]{2}{*}{ Raw salt (solution) } & \multicolumn{3}{|c|}{ Concentration of solution } & \multirow{2}{*}{$\begin{array}{c}\text { Surface area } \\
\qquad\left(\mathrm{m}^{2} / \mathrm{g}\right)\end{array}$} \\
\hline & & $\begin{array}{l}\text { wt } \% \text { of salt } \\
\text { (anhydride) }\end{array}$ & $\mathrm{g}($ metal $) / \mathrm{m} l$ & $\mathrm{pH}$ & \\
\hline $10 \% \mathrm{Co}-\mathrm{Al}_{2} \mathrm{O}_{3}$ & Co $\left(\mathrm{NO}_{3}\right)_{2}$ aq. & 12.2 & $5.06 \times 10^{-2}$ & 4 & 46 \\
\hline $10 \% \mathrm{Ni}-\mathrm{Al}_{2} \mathrm{O}_{3}$ & $\mathrm{Ni}\left(\mathrm{NO}_{3}\right)_{2}$ aq. & 12.6 & $5.50 \times 10^{-2}$ & 4 & 50 \\
\hline $10 \% \mathrm{Fe}-\mathrm{Al}_{2} \mathrm{O}_{3}$ & $\mathrm{Fe}\left(\mathrm{NO}_{3}\right)_{2}$ aq. & 15.9 & $4.97 \times 10^{-2}$ & 1. & 47 \\
\hline $0.3 \% \mathrm{Pt}-\mathrm{Al}_{2} \mathrm{O}_{3}$ & $\mathrm{H}_{2} \mathrm{PtCl}_{6}$ aq. & 0.23 & $1.12 \times 10^{-3}$ & 9 & 45 \\
\hline $0.3 \% \mathrm{Rh}-\mathrm{Al}_{2} \mathrm{O}_{3}$ & $\mathrm{RhCl}_{3}$ aq. & 0.32 & $1.56 \times 10^{-3}$ & 3 & 56 \\
\hline $0.3 \% \mathrm{Ru}-\mathrm{Al}_{2} \mathrm{O}_{3}$ & $\mathrm{RuCl}_{3}-\mathrm{NH}_{3}$ complex ap. & 0.46 & $4.81 \times 10^{-4}$ & 11 & 45 \\
\hline $0.3 \% \mathrm{Pd}-\mathrm{Al}_{2} \mathrm{O}_{3}$ & $\mathrm{Pd}-\mathrm{HCl}(0.1 \mathrm{~N}) \mathrm{aq}$ & 0.26 & $1.54 \times 10^{-3}$ & 2 & 51 \\
\hline
\end{tabular}

$\mathrm{Al}_{2} \mathrm{O}_{3}$ was pre-calcined at $1,100^{\circ} \mathrm{C}$ for $3 \mathrm{hrs}$. After impregnation and drying, each catalyst was reduced with flowing $\mathrm{H}_{2}$ increasing $\left(10^{\circ} \mathrm{C} / \mathrm{min}\right)$ from room temperature to $550^{\circ} \mathrm{C}$ for ca. $1 \mathrm{hr}$, and then at $550^{\circ} \mathrm{C}$ for ca. $1 \mathrm{hr}$

\section{4. 実験方法}

実験装置は前報1)と同じものである。すなわち，石 英製管型反応器 (内径 $12 \mathrm{~mm}$ ) の中央部に触媒を充てん 固定し, 常圧流通系で行なった。触媒は含漫・乾燥後 のもの $(1 \mathrm{~m} l ; 0.90 \sim 1.10 \mathrm{~g})$ を充てんし, 系内を $\mathrm{N}_{2}$ $\left(300 \mathrm{Ncm}^{2} / \mathrm{min}\right)$ で置換し, その後 $\mathrm{H}_{2}\left(50 \mathrm{Ncm}^{3} / \mathrm{min}\right)$ 流中で室温から $550^{\circ} \mathrm{C}$ まで昇温 $\left(10^{\circ} \mathrm{C} / \mathrm{min}\right)$ し, $550^{\circ} \mathrm{C}$ で約 1 時間 (昇温開始から合わせて 2 時間), 還元し, らたたび $\mathrm{N}_{2}$ で系内を置愌しながら所定の反応温度に 調節した。入口ガス組成は $10 \% \mathrm{CH}_{3} \mathrm{OH}-\mathrm{N}_{2}$ および10 $\% \mathrm{CH}_{3} \mathrm{OH}-40 \% \mathrm{H}_{2} \mathrm{O}-\mathrm{N}_{2}$ で全流速は $500 \mathrm{Ncm}^{3} / \mathrm{min}$ (空 間速度 SV : $3.0 \times 10^{4} \mathrm{hr}^{-1}$ ) で行なった。

さて，反応管出ロガスの定量法も前報1)と同じで凝 縮器, アイストラップ, 塩化カルシウム・過塩素酸マ グネシウムの充てん層を通して, $\mathrm{H}_{2} \mathrm{O}$ および $\mathrm{CH}_{3} \mathrm{OH}$ を除去したのちガスクロマトグラフィーで定量した。 すなわち, $\mathrm{H}_{2}$ はモレキュラーシーブ $5 \mathrm{~A}, 3 \mathrm{~m}$ (分離 カラム I ), モレキュラーシーブ $5 \mathrm{~A}, 2 \mathrm{~m}$ (分離カラ ム II $; \mathrm{O}_{2}, \mathrm{~N}_{2}, \mathrm{CH}_{4}, \mathrm{CO}$ 分離), キャリヤーガス $\mathrm{He}$, $\mathrm{TCD}$ 温度 $100^{\circ} \mathrm{C}$ ，カラム温度 $70^{\circ} \mathrm{C}$ で測定した。

\section{5. 実験結果ならびに考察}

$\mathrm{CH}_{2} \mathrm{OH}$ の分解では, $10 \% \mathrm{CH}_{3} \mathrm{OH}-\mathrm{N}_{2}$ を $500 \mathrm{Ncm}^{3}$ / min で供給しているので, $\mathrm{CH}_{3} \mathrm{OH} \rightarrow \mathrm{CO}+2 \mathrm{H}_{2}$ ( Table 1 のN. 1 ）の反応による $\mathrm{CO}$ および $\mathrm{H}_{2}$ の最大生成速 度は，それぞれ $50 \mathrm{Ncm}^{3} / \mathrm{min}$ および $100 \mathrm{Ncm}^{3} / \mathrm{min}$ と なり，また， $\mathrm{CH}_{3} \mathrm{OH}$ のスチームリフォーミングでは， $10 \% \mathrm{CH}_{3} \mathrm{OH}-40 \% \mathrm{H}_{2} \mathrm{O}-\mathrm{N}_{2}$ を $500 \mathrm{Ncm}^{3} / \mathrm{min}$ で供給 しているので, $\mathrm{CH}_{3} \mathrm{OH}+\mathrm{H}_{2} \mathrm{O} \rightarrow \mathrm{CO}_{2}+3 \mathrm{H}_{2}$ (Table 1 の№.3）の反応による $\mathrm{CO}_{2}$ および $\mathrm{H}_{2}$ の最大生成速度 は，それぞれ $50 \mathrm{Ncm}^{2} / \mathrm{min}$ 打よび $150 \mathrm{Ncm}^{3} / \mathrm{min}$ と
なることになる。な扮， $\mathrm{CH}_{3} \mathrm{OH}$ のスチームリフォー ミングで, $\mathrm{H}_{2} \mathrm{O} / \mathrm{CH}_{3} \mathrm{OH}$ モル比を 4.0 と高くしたのは, 平衡論的考察(2)で述べたように，高変換率を得るため である。

\section{1 無触媒下に打ける $\mathrm{CH}_{3} \mathrm{OH}$ の分解}

まず，無触媒下にむける $\mathrm{CH}_{3} \mathrm{OH}$ 分解の開始温度と 分解生成ガスを検討し，結果をFig. 3 に示した。すな わち, $\mathrm{CH}_{3} \mathrm{OH}$ の分解反応は無触媒下（ブランク実験） では，750〜800 Cから急激に起こりはじめ，生成 $\mathrm{H}_{2} /$ $\mathrm{CO}$ のモル比は 2.0 となり $850^{\circ} \mathrm{C}$ 付近以上で, $\mathrm{CH}_{4}$ の 生成が，ごくわずか認められるだけで，ほとんど CO

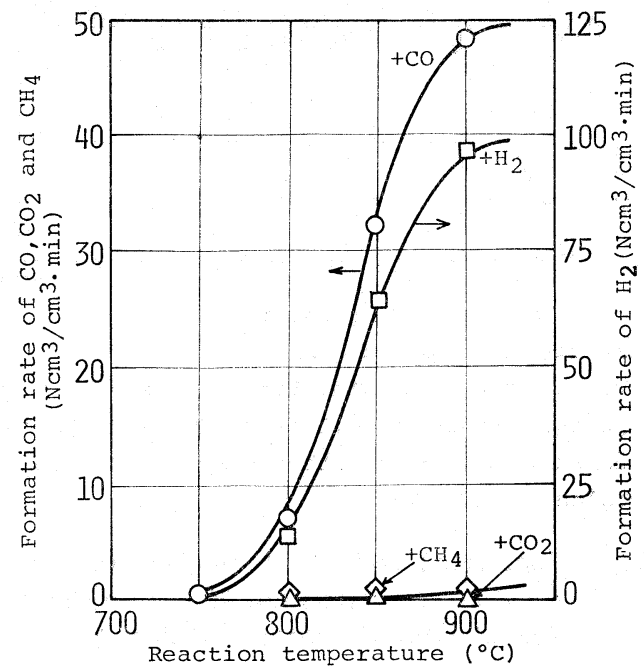

Inlet gas : $10 \% \mathrm{CH}_{3} \mathrm{OH}-\mathrm{N}_{2}$, Total feed rate: $500 \mathrm{Ncm}^{3} / \mathrm{min}$

Fig. 3 Non-catalytic cracking of $\mathrm{CH}_{3} \mathrm{OH}$ -Blank test- 
と $\mathrm{H}_{2}$ のみに分解される。

$5.2 \mathrm{CH}_{3} \mathrm{OH}$ の分解执よびスチームリフォーミン グに対する各種触媒の活性と選択性

$\mathrm{CH}_{3} \mathrm{OH}$ の分解およびスチームリフォーミングに対 するそれぞれの触媒の $\mathrm{H}_{2}$ 生成への活性・選択性を対

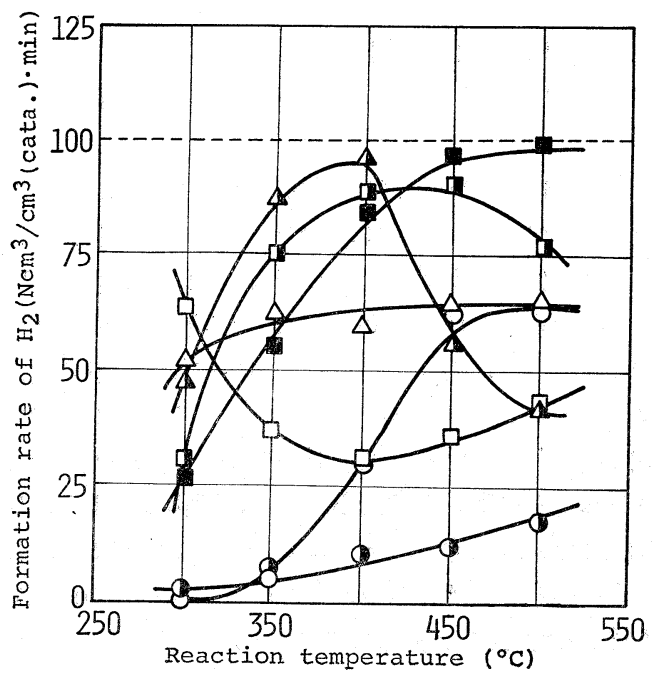

Inlet gas : $10 \% \mathrm{CH}_{3} \mathrm{OH}-\mathrm{N}_{2}, \mathrm{SV}: 3.0 \times 104 \mathrm{hr}^{-1}$

口: $10 \% \mathrm{Ni}, \Delta: 10 \% \mathrm{Co}, 0: 10 \% \mathrm{Fe}, \quad 0: 0.3 \% \mathrm{Ru}$

$\Delta: 0.3 \% \mathrm{Rh}, \mathbf{\square}: 0.3 \% \mathrm{Pd}, \mathbf{1}: 0.3 \% \mathrm{Pt}$

Fig. 4 Formation rate of $\mathrm{H}_{2}$ in cracking of $\mathrm{CH}_{3} \mathrm{OH}$ over various $\mathrm{Al}_{2} \mathrm{O}_{3}$-supported metal catalysts

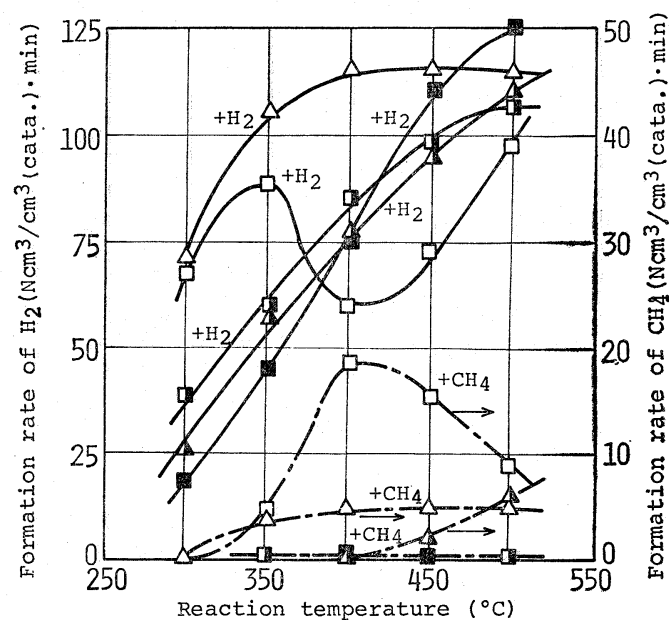

Inlet gas : $10 \% \mathrm{CH}_{3} \mathrm{OH}-40 \% \mathrm{H}_{2} \mathrm{O}-\mathrm{N}_{2}, \mathrm{SV}: 3.0 \times 10^{4} \mathrm{hr}^{-1}$

ㅁ: $10 \% \mathrm{Ni}, \Delta: 10 \% \mathrm{Co}, \Delta: 0.3 \% \mathrm{Rh}, 0.3 \% \mathrm{Pd}$

口: $0.3 \% \mathrm{Pt}$

Fig. 5 Formation rate of $\mathrm{H}_{2}$ and $\mathrm{CH}_{4}$ in reforming of $\mathrm{CH}_{3} \mathrm{OH}$ with steam over various $\mathrm{Al}_{2} \mathrm{O}_{3}$-supported metal catalysts
比した結果をFig. 4 およびFig. 5 に示した。すなわち $\mathrm{CH}_{3} \mathrm{OH}$ の分解 (Fig. 4) では, 無触媒下の場合と比 べると，かなり低温化され触媒によっては $300^{\circ} \mathrm{C}$ 付近 以下でも進行する。とくに $\mathrm{Ru}$ と Fe は低活性である が, $\mathrm{Pt}, \mathrm{Pd}, \mathrm{Rh}$ は高活性で $\mathrm{Co}, \mathrm{Ni}$ はこれらにつぐ。

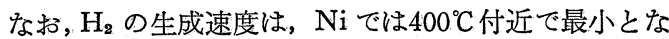
り, Rh では $400^{\circ} \mathrm{C}$ 付近をこえると急激に低下した。ま た, $\mathrm{CH}_{3} \mathrm{OH}$ のスチームリフォーミング (Fig. 5) で は，Ru と Feは，ほとんど活性を示さず，とくに Co が低温で活性で， $\mathrm{Pt}, \mathrm{Pd}, \mathrm{R}_{\mathrm{h}}$ は活性である。また $\mathrm{Ni}$ は $\mathrm{CH}_{3} \mathrm{OH}$ の分解の場合と同様に $400^{\circ} \mathrm{C}$ 付近で, $\mathrm{H}_{2}$ 生 成速度が最小になる。これらの理由については，あと で, 生成 $\mathrm{CO}$ 户 $\mathrm{CO}_{2}$ の生成 $\mathrm{H}_{2}$ によるメタネーショ ンの副反応の影響と関連して述べる。

なお, Table 1 のNo.4 の反応が起こると, $\mathrm{HCHO}$ が 生成するので, この $\mathrm{HCHO}$ の生成の有無を知るため に，出ロガスを直接採取し，ガスクロマトグラフで分 析 (Porapak Q : $3 \mathrm{~m}, 70^{\circ} \sim 180^{\circ} \mathrm{C}$ まで $6{ }^{\circ} \mathrm{C} / \mathrm{min}$ で昇 温, T.C.D.インジェクション温度 $200^{\circ} \mathrm{C}, 70 \mathrm{~mA}$ ) 乙 たところ， $\mathrm{Ni}$ および $\mathrm{Pd}$ では， $500^{\circ} \mathrm{C}$ 付近の高温で， $\mathrm{HCHO}$ の生成がわずか認められたが，それ以下の温度 では，また他の触媒では $\mathrm{HCHO}$ の生成は確認できな かった。

5.3. $\mathrm{Pt}-\mathrm{Al}_{2} \mathrm{O}_{3}$ 触媒上の $\mathrm{CH}_{3} \mathrm{OH}$ の分解执よびスチ ームリフォーミング

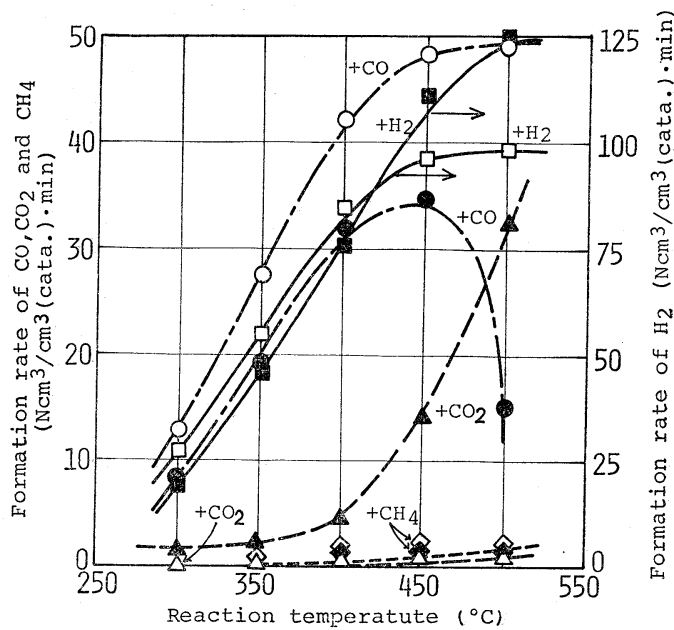

Inlet gas : $10 \% \mathrm{CH}_{3} \mathrm{OH}-\mathrm{N}_{2}(\mathrm{O}, \triangle, \square, \diamond), 10 \% \mathrm{CH}_{3} \mathrm{OH}-40 \% \mathrm{H}_{2} \mathrm{O}$ $-\mathrm{N}_{2}(\bullet, \Delta, \bullet), \mathrm{SV}: 3.0 \times 10^{4} \mathrm{hr}^{-1}$

Fig. 6 Formation rate of $\mathrm{CO}, \mathrm{H}_{2}, \mathrm{CO}_{2}$, and $\mathrm{CH}_{4}$ in cracking of $\mathrm{CH}_{3} \mathrm{OH}$ and reforming of $\mathrm{CH}_{3} \mathrm{OH}$ with steam over $0.3 \%$ $\mathrm{Pt}-\mathrm{Al}_{2} \mathrm{O}_{3}$ catalyst 
Pt が両反応系に対して，ともに最も活性であること は，すでに述べたが，Fig. 6 亿示したように $\mathrm{CH}_{3} \mathrm{OH}$ の分解では $\mathrm{CO}_{2}$ や $\mathrm{CH}_{4}$ の副生はほとんぞなく，選択 性はきわめて高い。しかし， $\mathrm{CH}_{3} \mathrm{OH}$ のスチームリフ ォーミングでは, $\mathrm{CH}_{4}$ は, ほとんぞ副生しないが, 400 $\sim 450^{\circ} \mathrm{C}$ 付近をこ元ると，急激に $\mathrm{CO}$ の生成が低下す るとともに $\mathrm{CO}_{2}$ の生成が増大した。これは， $\mathrm{CO}$ の転 化反応 $\left(\mathrm{CO}+\mathrm{H}_{2} \mathrm{O} \rightarrow \mathrm{CO}_{2}+\mathrm{H}_{2} ; \mathrm{No}\right.$.2) 飞よるもので あり, $\mathrm{Pt}$ は $400^{\circ} \mathrm{C}$ 付近以上では $\mathrm{CO}$ の転化反応に対し ても高い活性を示す。このことは, 本実験条件 (SV : $3.0 \times 10^{4} \mathrm{hr}^{-1}$ ) 下の $450^{\circ} \mathrm{C}$ 付近以上飞おける $\mathrm{CH}_{3} \mathrm{OH}$ の 分解では, $\mathrm{CH}_{3} \mathrm{OH}$ の変換率は $100 \%$ 近くに達し, $\mathrm{H}_{2}$ 生成速度はN0.1 の反応量論量の $100 \mathrm{Ncm}^{3} / \mathrm{min}$ 飞達す るのに対し，スチームリフォーミングでは, $\mathrm{H}_{2}$ の生成 速度も増大して $125 \mathrm{Ncm}^{3} / \mathrm{min}$ 飞達していることから も肯かれる。

$5.4 \mathrm{Rh}-\mathrm{Al}_{2} \mathrm{O}_{3}$ 触媒上の $\mathrm{CH}_{3} \mathrm{OH}$ の分解およびス チームリフォーミング

Fig. 7 に Rh の場合の結果を示したようと, $\mathrm{CH}_{3} \mathrm{OH}$ の分解では, $400^{\circ} \mathrm{C}$ 付近以下では, $\mathrm{CO}$ と $\mathrm{H}_{2}$ に分解し, $400^{\circ} \mathrm{C}$ 付近以上になると, $\mathrm{SV}=3.0 \times 10^{4} \mathrm{hr}^{-1}$ では $\mathrm{CH}_{8}$ $\mathrm{OH}$ の変換率はほほ果100\%に達するが，急激に $\mathrm{CO}$ と $\mathrm{H}_{2}$ の生成は減少し, これに伴なって $\mathrm{CH}_{4}$ の生成が增 大する。これは分解生成した $\mathrm{CO}$ と $\mathrm{H}_{2}$ が， No. $6 \sim \mathrm{No}$. 8 のメタネーションを起こすからである。また，メタ

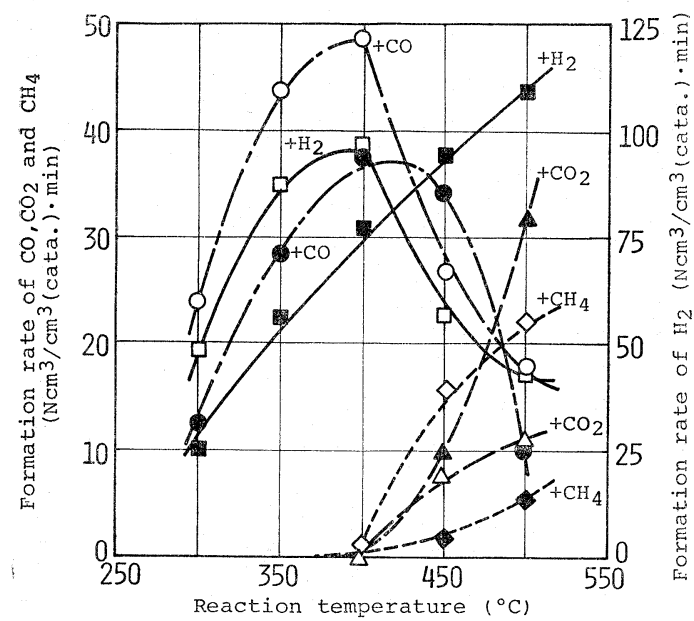

Inlet gas : $10 \% \mathrm{CH}_{3} \mathrm{OH}-\mathrm{N}_{2}(\mathrm{O}, \triangle, \square, \diamond), 10 \% \mathrm{CH}_{3} \mathrm{OH}-40 \% \mathrm{H}_{2} \mathrm{O}$ $-\mathrm{N}_{2}(\mathrm{~A}, \mathrm{SV}: 3.0 \times 104 \mathrm{hr}-\mathrm{I}$

Fig. 7 Formation rate of $\mathrm{CO}, \mathrm{H}_{2}, \mathrm{CO}_{2}$ and $\mathrm{CH}_{4}$ in cracking of $\mathrm{CH}_{3} \mathrm{OH}$ and reforming of $\mathrm{CH}_{3} \mathrm{OH}$ with steam over $0.3 \% \mathrm{Rh}$ $\mathrm{Al}_{2} \mathrm{O}_{3}$ catalyst
ネーションで生成した $\mathrm{H}_{2} \mathrm{O}$ と $\mathrm{CO}$ の反応 ( $\mathrm{CO}$ の転 化；№.2）飞よって $\mathrm{CO}_{2}$ の生成子起こるようになる。 しかし，スチームリフォーミングでは， $\mathrm{CH}_{4}$ の生成は 極度に抑制され，Pt の場合と同じょうに，400足付近 をこ觉ると，CO の転化反応(No.2)が急激に起こりは じめ, $\mathrm{CO}$ のいちじるしい減少に伴なって $\mathrm{H}_{2}$ と $\mathrm{CO}_{2}$ の生成がいちじるしく増大する。

$5.5 \mathrm{Pd}-\mathrm{Al}_{2} \mathrm{O}_{3}$ 触媒上の $\mathrm{CH}_{3} \mathrm{OH}$ の分解打よびス チームリフォーミング

Fig. 8 にPd の場合の結果を示したように, $\mathrm{CH}_{3} \mathrm{OH}$ の分解では, $\mathrm{SV}=3.0 \times 10^{4} \mathrm{hr}^{-1}$ 下の $400 \sim 450^{\circ} \mathrm{C}$ で $\mathrm{H}$ と $\mathrm{CO}$ の生成量が最大に達し, それ以下の温度では $\mathrm{H}_{2}^{2}$ そ CO のみが生成するが, それ以上の温度でも, Rh の 場合にみられた $\mathrm{CO}_{2}$ や $\mathrm{CH}_{4}$ の副生は無視しうる程度 であった。しかし， $\mathrm{H}_{2}$ 飞比へてて $\mathrm{CO}$ の方が減少速度 が大きくなっているのは，既述のように HCHO の副 生（NNo.4 の反応）が考兄られるが，理由は，目下，明 らかでない。他方, スチームリフォーミングでは, $\mathrm{Pt}$ や Rh の場合と比べると, CO の転化 (No.2 の反応) 飞対する活性は，きわめて低く，500 $\mathrm{C}$ 付近で，ある程 度, 認められたにすぎない。

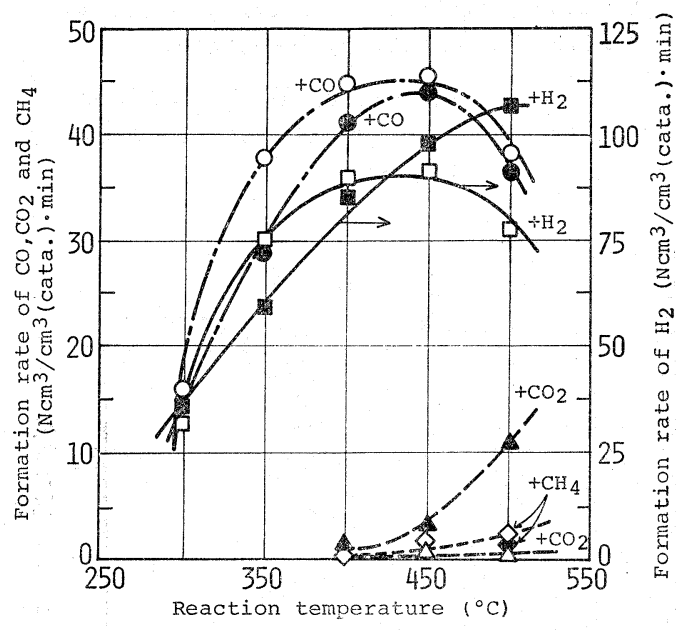

Inlet gas : $10 \% \mathrm{CH}_{3} \mathrm{OH}-\mathrm{N}_{2}(\mathrm{O}, \triangle, \square, \diamond), 10 \% \mathrm{CH}_{3} \mathrm{OH}-40 \% \mathrm{H}_{2} \mathrm{O}$ $-\mathrm{N}_{2}\left(\mathrm{~A}, \mathrm{SV}: 3.0 \times 10^{4} \mathrm{hr}^{-1}\right.$

Fig. 8 Formation rate of $\mathrm{CO}, \mathrm{H}_{2}, \mathrm{CO}_{2}$ and $\mathrm{CH}_{4}$ in cracking of $\mathrm{CH}_{3} \mathrm{OH}$ over $0.3 \% \mathrm{Pd}$ $-\mathrm{Al}_{2} \mathrm{O}_{3}$ catalyst

$5.6 \mathrm{Co}-\mathrm{Al}_{2} \mathrm{O}_{3}$ 触媒上の $\mathrm{CH}_{3} \mathrm{OH}$ の分解抢よびス チームリフォーミング

Co の場合の結果を Fig. 9 亿示したが，他の触媒と は，かなり様相を異にした結果が得られた。すなわち， その一つは, $\mathrm{CH}_{3} \mathrm{OH}$ の分解で $\mathrm{CH}_{4}$ と $\mathrm{CO}_{2}$ が $400^{\circ} \mathrm{C}$ 付 


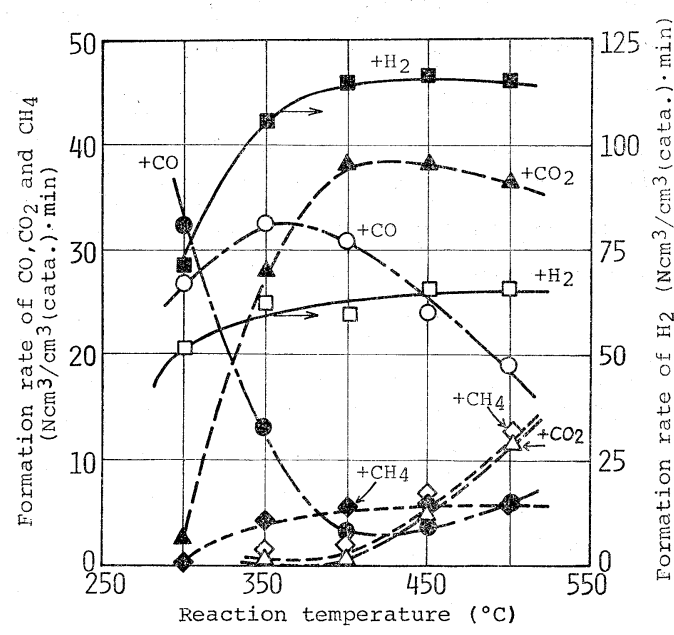

Inlet gas : $10 \% \mathrm{CH}_{3} \mathrm{OH}-\mathrm{N}_{2}(\mathrm{O}, \Delta, \square, \diamond), 10 \% \mathrm{CH}_{3} \mathrm{OH}-40 \% \mathrm{H}_{2} \mathrm{O}$ $-\mathrm{N}_{2}\left(\mathbf{A}, \mathbf{0}, \mathrm{BV}: 3.0 \times 10^{4} \mathrm{hr}-1\right.$

Fig. 9 Formation rate of $\mathrm{CO}, \mathrm{H}_{2}, \mathrm{CO}_{2}$ and $\mathrm{CH}_{4}$ in cracking of $\mathrm{CH}_{3} \mathrm{OH}$ and reforming of $\mathrm{CH}_{3} \mathrm{OH}$ with steam over $10 \% \mathrm{Co}$ $\mathrm{Al}_{2} \mathrm{O}_{3}$ catalyst

近以上で，絶觉ず等モル生成したことである。これは 生成した $\mathrm{CO}$ と $\mathrm{H}_{2}$ が, $\mathrm{No} .8$ の $\mathrm{CO}+\mathrm{H}_{2} \rightarrow 1 / 2 \mathrm{CH}_{4}+1 / 2$ $\mathrm{CO}_{2}$ の反応 (これはNo.6のメタネーションとこの反応 によって生成した $\mathrm{H}_{2} \mathrm{O}$ によるNo.2 の $\mathrm{CO}$ の転化反応 の組合わせであると考兄られる）を起こしたものと思 われる。もらーつは, スチームリフォーミングの場合, $350^{\circ} \mathrm{C}$ 付近の低温域でも, $\mathrm{CH}_{3} \mathrm{OH}$ 分解飞対するより も, $\mathrm{H}_{2}$ の生成に対してかなり高い活性を示したこと である。これは，低温域で CO の転化（No.2 の反応） 飞対して高い活性を示すことによるものであるが，こ の場合, 共存 $\mathrm{H}_{2} \mathrm{O}$ によって Co が酸化され酸化物に 変化し，これが触媒作用を示したものと思われるが， 酸化コバルトの生成はX線回折では確認できなかっ た。以上の現象については, 今後, さらに検討を要す るものと考えている。

$5.7 \mathrm{Ni}-\mathrm{Al}_{2} \mathrm{O}_{3}$ 触媒上の $\mathrm{CH}_{3} \mathrm{OH}$ の分解和よびス チームリフォーミング

$\mathrm{Ni}$ の場合の結果をFig.10に示したが，Ni は，周知 のように $\mathrm{CO}$ や $\mathrm{CO}_{2}$ のメタネーション触媒（さらに 高温域では, メタネーションの逆反応すなわち $\mathrm{CH}_{4}$ の スチームリフォーミングの触媒でもある1。)であるの で, $\mathrm{CH}_{4} \mathrm{OH}$ の分解においても生成 $\mathrm{CO}$ の生成 $\mathrm{H}_{2}$ 飞 よるメタネーションが起こり(もっとも本データでは, $300^{\circ} \mathrm{C}$ 付近以下では, $\mathrm{H}_{2}$ と $\mathrm{CO}$ のみに分解する), 400 ${ }^{\circ} \mathrm{C}$ 付近で $\mathrm{H}_{2}$ と $\mathrm{CO}$ の生成が最小となるとともに $\mathrm{CH}_{4}$

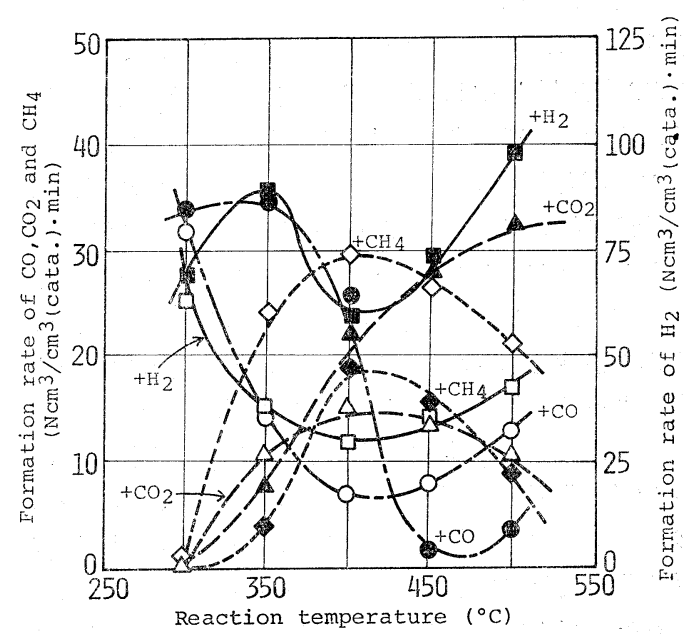

Inlet gas : $10 \% \mathrm{CH}_{3} \mathrm{OH}-\mathrm{N}_{2}(\mathrm{O}, \triangle, \square, \diamond), 10 \% \mathrm{CH} 3 \mathrm{OH}-40 \% \mathrm{H}_{2} \mathrm{O}$

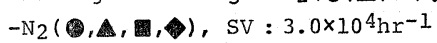

Fig. 10 Formation rate of $\mathrm{CO}, \mathrm{H}_{2}, \mathrm{CO}_{2}$ and $\mathrm{CH}_{4}$ in cracking of $\mathrm{CH}_{3} \mathrm{OH}$ and reforming of $\mathrm{CH}_{3} \mathrm{OH}$ with steam over $10 \%$ $\mathrm{Ni}-\mathrm{Al}_{2} \mathrm{O}_{3}$ catalyst

の生成は最大を示す。また，スチームリフォーミング 飞执いても，かなりの $\mathrm{CH}_{4}$ を副生し， $\mathrm{H}_{2}$ の生成は， やはり $400^{\circ} \mathrm{C}$ 付近で最小となり, これ以上の温度にな ると，CO の転化（No.2 の反応）飞よって CO の生成 はいちじるしく減少し, $\mathrm{H}_{2}$ と $\mathrm{CO}_{2}$ の生成は急激に増 大するなど，生成ガス組成は反応温度領域によってい ちじるしく変動するので, とくに $\mathrm{Ni}$ 触媒上の $\mathrm{CH}_{8} \mathrm{OH}$ の分解やスチームリフォーミングで, $\mathrm{CO}$ と $\mathrm{H}_{2}$ の合 成ガスを得ようとする場合には， $\mathrm{CH}_{4}$ の副生を伴なわ ない $300^{\circ} \mathrm{C}$ 付近以下で行なう必要がある。

\section{8 その他}

活性の経時变化を短時間（約 8 時間）ではあるが検 討したところ, 貴金属触媒では, 反応初期から, 鉄族 触媒では10３0分後からほほとんど定常活性を示した。 また, 鉄族触媒とくに Ni では, 主として CO の分解 (No.12 の反応) 飞よる炭素析出反応が認められだ。

\section{6. 結 言}

常圧下での $\mathrm{CH}_{3} \mathrm{OH}$ の分解反応抢よびスチームりフ ォーミング反応を壮族元素 $(\mathrm{Pt}, \mathrm{Rh}, \mathrm{Pd}, \mathrm{Ru}, \mathrm{Co}, \mathrm{Ni}$, $\mathrm{Fe}$ ) の $\mathrm{Al}_{2} \mathrm{O}_{3}$ 担持触媒 ${ }^{1}$ ) (平均粒径 : $0.9 \mathrm{~mm}$ ) を用い て, 空間速度を $\mathrm{SV}=3.0 \times 10^{4} \mathrm{hr}^{-1}$ と一定にして 検討 し，つぎのような結果・知見を得た。

1) $\mathrm{CH}_{3} \mathrm{OH}$ の分解は無触媒下では, $700^{\circ} \mathrm{C}$ 付近以上 の高温を必要とし, $\mathrm{CH}_{3} \mathrm{OH} \rightarrow \mathrm{CO}+2 \mathrm{H}_{2}$ の反応量論式 にしたがって $\mathrm{H}_{2}$ と $\mathrm{CO}$ を生成する。しかし，触媒を 
いる用と, $\mathrm{Ru}$ と $\mathrm{Fe}$ 以外は $300^{\circ} \mathrm{C}$ 付近以下の低温でも 活性を示し， $\mathrm{H}_{2}$ と $\mathrm{CO}$ に分解する。しかし, $\mathrm{Fe}$ は $400^{\circ} \mathrm{C}$ 付近以上では, ある程度の活性を示すようにな る。また，一般に多かれ少かれ $\mathrm{CH}_{4}$ を副生する。

2) $\mathrm{CH}_{3} \mathrm{OH}$ のスチームリフォーミングは, $\mathrm{CH}_{3} \mathrm{OH}$ の分解に続いて, 生成 $\mathrm{CO}$ の転化反応 $\left(\mathrm{CO}+\mathrm{H}_{2} \mathrm{O} \rightarrow\right.$ $\left.\mathrm{CO}_{2}+\mathrm{H}_{2}\right)$ が, ぞの程度, 起こるかということによっ て意義づけられ， $\mathrm{Ru}$ と $\mathrm{Fe}$ は $\mathrm{H}_{2} \mathrm{O}$ が共存すると，ほ とんど活性を示さなくなる。また,一般に， $\mathrm{H}_{2} \mathrm{O}$ の共 存によって $\mathrm{CH}_{4}$ の副生は抑制される。

3) $\mathrm{Pt}-\mathrm{Al}_{2} \mathrm{O}_{3}$ 触媒は両反応に対して最も活性で, $\mathrm{CH}_{3} \mathrm{OH}$ 分解では $\mathrm{H}_{2}$ と $\mathrm{CO}$ のみを生成し, スチーム リフォーミングでも $\mathrm{CH}_{4}$ をほとんど副生せず，選択 性も最子優れている。スチームリフォーミングで, 400 $\sim 450^{\circ} \mathrm{C}$ 以上になると, 生成 $\mathrm{CO}$ の転化反応対して 多高い活性を示すようになる。したがって, 入口 $\mathrm{H}_{2} \mathrm{O} /$ $\mathrm{CH}_{3} \mathrm{OH}$ モル比を 4.0 以上にし, 空間速度を小さくす れば， $\mathrm{H}_{2}$ のみの製造も可能になる。

4) $\mathrm{Rh}-\mathrm{Al}_{2} \mathrm{O}_{3}$ 触媒は, $400^{\circ} \mathrm{C}$ 付近以下の $\mathrm{CH}_{3} \mathrm{OH}$ 分 解では $\mathrm{H}_{2}$ と $\mathrm{CO}$ のみを生成するが，それ以上の温度 になると、メタネーション反応子優勢になり，かなり の $\mathrm{CH}_{4}$ を副生する。スチームリフォーミングでは, $400^{\circ} \mathrm{C}$ 付近をこえると, Pt の場合と同じょうに, CO の 転化反応に対して高い活性を示すようになり, 他方, $\mathrm{CH}_{4}$ の副生は $\mathrm{H}_{2} \mathrm{O}$ の共存でかなり抑制される。

5) $\mathrm{Pd}-\mathrm{Al}_{2} \mathrm{O}_{3}$ 触媒は, $4.00 \sim 450^{\circ} \mathrm{C}$ 以下の $\mathrm{CH}_{3} \mathrm{OH}$ 分解では, $\mathrm{H}_{2}$ と $\mathrm{CO}$ のみ生成し, それ以上の温度 でも $\mathrm{CO}_{2}$ や $\mathrm{CH}_{4}$ の副生は無視しうる程度であり, $\mathrm{Pt}$ 之同様に選択性は高い。スチームリフォーミングで は, $\mathrm{CO}$ の転化反応に対する活性はきわめて低く, $\mathrm{H}_{2}$ のみの製造には不適である。
6) $\mathrm{Co}-\mathrm{Al}_{2} \mathrm{O}_{3}$ 触媒は, 他の触媒とかなり異なった 挙動を示す。すなわち, $400^{\circ} \mathrm{C}$ 付近以上の $\mathrm{CH}_{3} \mathrm{OH}$ 分 解で $\mathrm{H}_{2}$ と $\mathrm{CO}$ のほかに, 等モルの $\mathrm{CH}_{4}$ と $\mathrm{CO}_{2}$ を生 成した。また,スチームリフォーミングでは, $300^{\circ} \mathrm{C}$ 付 近以下でも $\mathrm{CO}$ の転化反応に対して高い活性を示し, 低温域では, $\mathrm{Pt}$ の場合と同じように, $\mathrm{H}_{2}$ のみの製造 の可能性が示唆された。

7) $\mathrm{Ni}-\mathrm{Al}_{2} \mathrm{O}_{3}$ 触媒は, 両反応系の $300^{\circ} \mathrm{C}$ 付近以下て は， $\mathrm{H}_{2}$ と $\mathrm{CO}$ のみの製造は可能のようであるが，温 度が高くなると, 他の触媒に比べて, メタネーション 反応に対する活性がいちじるしく高く, $\mathrm{CH}_{3} \mathrm{OH}$ 分解 に括いても, $400^{\circ} \mathrm{C}$ 付近で $\mathrm{CH}_{4}$ の生成が最大 $\left(\mathrm{H}_{2}\right.$ の 生成は最小）となる。しかし, $\mathrm{CH}_{3} \mathrm{OH}$ のみから $\mathrm{CH}_{4}$ のみを製造することは，量論関係からわかるようと不 能である。また，スチームリフォーミングでむかなり の $\mathrm{CH}_{4}$ を副生し, やはり $400^{\circ} \mathrm{C}$ 付近で $\mathrm{CH}_{4}$ の生成は最 大となる。しかし, これ以上の温度になると, CO の 転化反応も優勢になり, $\mathrm{H}_{2}$ 濃度の高いガスは生成され るが，主として CO の分解による炭素析出が問題であ る。

8）今後は，酸化性ガスであるスチーム共存下のリ フォーミングにおける触媒の作用状態を解明し, 複合 触媒, たとえば Pt-Co 系触媒などの検討を推進させ たい。

\section{文献}

1）笠岡成光, 白神隆, 宮崎宏, 燃協誌, 59, 25 (1980)

2) D.C.Fort, J.M. White, J.Catal., 42, 260 (1977)

3) H. Kobayashi, N. Takezawa, C. Minochi, Chem. Lett., 1347 (1976) 


\title{
Catalytic Thermal Decomposition and Stem Reforming of Methanol over Alumina Supported Metal of VIII group
}

\author{
Shigeaki KASAOKA and Takashi SHIRAGA
}

\section{(School of Engineering, Okayama University)}

SYNOPSIS:-For the purpose of exploring the prooess to prepare synthesis gas $\left(\mathrm{CO}+\mathrm{H}_{2}\right)$ or $\mathrm{H}_{2}$ from methanol, thermal decomposition $\left(\mathrm{CH}_{3} \mathrm{OH} \longrightarrow \mathrm{CO}+2 \mathrm{H}_{2}\right)$ and steam reforming $\left(\mathrm{CH}_{3} \mathrm{OH}+\mathrm{H}_{2} \mathrm{O} \longrightarrow \mathrm{CO}_{2}+3 \mathrm{H}_{2}\right)$ were investigated on $\mathrm{Al}_{2} \mathrm{O}_{3}$ supported metal ( $\mathrm{Pt}$, $\mathrm{Pd}, \mathrm{Ru}, \mathrm{Rh}, \mathrm{Co}, \mathrm{Ni}, \mathrm{Fe}$ ) catalysts.

The experiment was carried out by using a flow fixed bed reactor under an atmospheric pressure and at $300^{\circ} \sim 550^{\circ} \mathrm{C}$. The inlet gases were $10 \% \mathrm{CH}_{3} \mathrm{OH}-\mathrm{N}_{2}$ and $10 \% \mathrm{CH}_{3} \mathrm{OH}-40 \% \mathrm{H}_{2}$ $\mathrm{O}-\mathrm{N}_{2}$, and the total feed rate was $500 \mathrm{Ncm}^{3} / \mathrm{min}$ per $1 \mathrm{ml}$ of each catalyst of average diameter $0.9 \mathrm{~mm}$ (space velocity : $3.0 \times 10^{4} \mathrm{hr}^{-1}$ ).

The following informations were obtained:

1) Decomposition of $\mathrm{CH}_{3} \mathrm{OH}$ under the absence of catalyst occurred at above ca. $700^{\circ} \mathrm{C}$ according to $\mathrm{CH}_{3} \mathrm{OH} \longrightarrow \mathrm{CO}+2 \mathrm{H}_{2}$, but the decomposition under the presence of catalysts except $\mathrm{Ru}$ and $\mathrm{Fe}$ occured at low temperatures below $300^{\circ} \mathrm{C}$.

2) Catalytic steam reforming was considered to be the consecutive reactions of $\mathrm{CH}_{3} \mathrm{OH} \longrightarrow$ $\mathrm{CO}+2 \mathrm{H}_{2}$ and $\mathrm{CO}+\mathrm{H}_{2} \mathrm{O} \longrightarrow \mathrm{CO}_{2}+\mathrm{H}_{2} \mathrm{O}$. Ru and $\mathrm{Fe}$ gave a litlle activity.

3) $\mathrm{Pt}$ was the most active for both reactions, and gave no formation of $\mathrm{CH}_{4}$.

4) $\mathrm{Pd}$ was very high active for decomposition of $\mathrm{CH}_{3} \mathrm{OH}$, but low active for shift reaction of $\mathrm{CO}$.

5) " $\mathrm{Rh}$ was active for both reactions, but accompanied the formation of a considerable amount of $\mathrm{CH}_{4}$.

6) $\mathrm{Co}$ gave the formation of equimolal $\mathrm{CH}_{4}$ and $\mathrm{CO}_{2}$ besides $\mathrm{CO}$ and $\mathrm{H}_{2}$ at decomposition of $\mathrm{CH}_{3} \mathrm{OH}$, and was very high active for shift reaction of $\mathrm{CO}$ as well as Pt.

7) $\mathrm{Ni}$ promoted considerably the methanation reactions in both reaction systems. 